AMERICAN JOURNAL BIOTECHNOLOGY AND MOLECULAR SCIENCES

ISSN Print: 2159-3698, ISSN Online: 2159-3701, doi:10.5251/ajbms.2012.2.1.6.14

(C) 2012, ScienceHuß, http://www.scihub.org/AJBMS

\title{
The hepato-protective potentials of Moringa oleifera leaf extract on alcohol-induced hepato-toxicity in wistar rat
}

\author{
${ }^{1 *}$ Saalu, L.C.; ${ }^{1}$ Ogunlade, B.; ${ }^{2}$ Ajayi, G.O.; ${ }^{3}$ Oyewopo, A.O. ${ }^{1}$ Akunna, G.G. \\ ${ }^{1}$ Ogunmodede, O.S. \\ ${ }^{1}$ Department of Anatomy, Lagos State University College of Medicine (LASUCOM) Ikeja, \\ Lagos, Nigeria. \\ ${ }^{2}$ Department of Medical Biochemistry, Lagos State University College of Medicine \\ (LASUCOM) Ikeja, Lagos, Nigeria. \\ ${ }^{3}$ Department of Anatomy, University of Ilorin, Kwara State, Nigeria. \\ ABSTRACT
}

\begin{abstract}
Alcohol (ethanol) is presently reputed to the most cause of disease development in humans. The liver is the human organ that is most frequently challenged in alcohol abuse by oral route in a process that involves generation of reactive oxygen species. In this study we evaluated the liver histology, liver oxidative stress and the activities of liver biomarker enzymes to investigate the capabilities of polyphenolic antioxidant-rich Moringa oleifera Leaf Extract to ameliorate liver derangement caused by alcohol. Three groups of Wistar rats were constructed for the study; A control group that received peanut oil (the vehicle) $300 \mathrm{mg} \mathrm{kg}^{-1}$ body weight, daily, orally, for 56 days, after saline $5 \mathrm{ml} \mathrm{kg}^{-1}$ body weight daily, orally for 56 days. The Moringa oleifera--alone group that received physiological saline $5 \mathrm{ml} \mathrm{kg}^{-1}$ body weight, daily, per oral for 56 days followed by Moringa oleifera leaf extract $300 \mathrm{mg} \mathrm{kg}^{-1}$ body weight, daily, orally for another 56 days. The alcohol-alone group was given alcohol $5 \mathrm{~g} \mathrm{~kg} \mathrm{k}^{-1}$ body weight, daily, per oral for 56 days followed by saline $5 \mathrm{ml} \mathrm{kg}^{-1}$ body weight, daily per oral for another 56 days. Finally, the alcohol plus Moringa oleifera group which were similarly given alcohol, but had Moringa oleifera $300 \mathrm{mg} \mathrm{kg}^{-1}$ body weight, daily, per oral after alcohol for another 56 days. Our results demonstrated that post-treatment with Moringa oleifera leaf extract attenuated the liver morphological, functional and oxidative status changes mediated by alcohol ingestion.
\end{abstract}

Key words: Moringa oleifera, alcohol, hepatotoxicity, Wistar rat

\section{INTRODUCTION}

Toxicity of alcohol consumption in the body involves the main organs of excretion and metabolism, especially the liver. The morbidity and mortality rate of heavy alcohol drinkers has since been reported to have reached 6.1\% (Wei et al.; 1999). Alcoholic liver disease (ALD) is one of the most serious consequences of chronic alcohol abuse in the world (Diehl, 2002). Tuma and Casey (2003) reported that the factors that mediate the occurrence of ALD are acetaldehyde, oxidative stress, hypoxia, immune response and membrane alterations.

The main reason why alcohol toxicity most commonly results in hepatic derangement has been reported to be due to the fact that approximately $80 \%$ of ingested alcohol is metabolized in the liver by a process that generates many reactive oxygen species (Venkatraman et al., 2004). Firstly, alcohol is metabolized into the highly toxic acetaldehyde by alcohol dehydrogenase in the liver, then acetaldehyde is oxidized to acetate by aldehyde oxidase or xanthine oxidase giving rise to Reactive oxygen species (ROS) via cytochrome P450 2E1 (Tuma and Casey, 2003). Secondly, chronic alcohol consumption increases Nitric oxide (NO) level which may lead to toxicity by peroxynitrite, a potent oxidant (Venkatraman et al., 2004). Hence, overproduction of reactive nitrogen species/ reactive oxygen species (RNS/ROS) may occur when its generation in a system exceeds the systems ability to neutralize and eliminate them.

It is in realization of this pathogenesis that Chambers et al. 1987 concluded that hepatic oxidative stress due to chronic alcohol consumption is due to decrease in anti- oxidant capacity of the liver which can damage the cell membranes and organelles with the release of reactive aldehydes. 
Moringa oleifera leaf extract (MO) is from Moringa oleifera Lamarck tree which is commonly called ben oil or drumstick tree. The tree is widely cultivated in Africa, Central and South America, Sri Lanka, India, Malaysia and the Philippines. In Nigeria it is mostly grown in the northern part and locally known as Zogeli among the Hausa speaking people. The Yoruba of South-West Nigeria call it ewe ile or igi iyaanu (because of its many medicinal uses).

$M$. oleifera is considered one of the world's most useful trees, as almost every part of the tree can be used for food, or has some other beneficial property. Furthermore extracts from all parts of the plant show pharmacological properties, recognized by popular use and corroborated by the scientific community (Oliveira et al., 1999). It is an exceptionally nutritious vegetable tree with a variety of potential uses (Ram, 1994). The leaves can be eaten fresh cooked or stored as dried powder for several months the pods, when young can be cooked; eaten like beans (National Research Council, 2006). Its oil and micronutrients have been reported to contain antimicrobial (Caceres et al., 1991), anti- inflammatory (Kurma and Mishra, 1998), and potent antioxidant (Saalu et al., 2011).

Furthermore, the leaf extract of $\mathrm{MO}$ regulates thyroid status (Tahiliani et al., 2000), maintenance of cholesterol levels (Ghasi et al., 2000). The active anti- oxidant properties of MO known to contains specific plant pigments includes carotenoids- lutein, chlorophyll, xanthins, alpha carotene and beta carotene. Other isolated phytochemicals of $\mathrm{MO}$ with antioxidant potential are quercetin, rutin, kaempferol and caffeoyqumic acids. Potent antioxidant vitaminsA, C, E (Siddhuraju and Becker, 2003; Aslam et al., 2005) and essential micronutrients with antioxidant ability are selenium and zinc (Fugile, 1999).

It is therefore, presently a settled fact that alcohol mediated hepato-toxicity is at least in part a result of generation of reactive oxygen species, and that moringa oleifera leaf extract contains active antioxidative agents. The aim of the present study is therefore to investigate the ameliorating potentials of the leaf extract of Moringa oleifera on alcohol mediated liver damage.

\section{MATERIALS AND METHODS}

Chemicals: Ethanol of E. Merck, Darmatadt, Germany was obtained from Biotechnology Co. Ltd, Yaba Lagos in the month of September, 2011. All reagents used in this research were of analytical grade.
Plant materials and the aqueous extraction procedure: Samples of leaves were collected from a plantation located at a village around Oke- Ogun in Oyo state, Nigeria in the month of September, 2011. They were transported to the laboratory of Anatomy department of Lagos State University College of Medicine, Ikeja, Lagos state, Nigeria and were authenticated by a staff in the herbarium of the Department of Botany, University of Lagos, Lagos state, Nigeria, where a voucher specimen was deposited for reference with specimen no. DSN 32. The leaves were thoroughly washed in sterile water and the water was then drained from the leaves.

Animals: Wistar rats were obtained from a breeding stock maintained in the Animal House of the College of Health Sciences, Ladoke Akintola University of Technology (LAUTECH), Ogbomoso and were authenticated by the Farm Director LAUTECH. The animals were housed in well ventilated wire-wooden cages in the Animal Facility of the Department of Anatomy, Lagos State University College of Medicine (LASUCOM), Ikeja, Lagos. An approval was sought and obtained from the Departmental Ethical Committee on Animal Use. The rats were maintained under standard natural photoperiodic condition of twelve hours of light alternating with twelve hours of darkness (i.e. L: D; 12h:12h photoperiod) at room temperature $(250 \mathrm{C}-260 \mathrm{C})$ and humidity of $65 \pm 5 \%$. They were allowed unrestricted access to water and rat chow (Feedwell Livestock Feeds Ltd, Ikorodu, Lagos, Nigeria). They were allowed to acclimatize for 28 days before the commencement of the experiments. The weights of the animals were estimated at procurement, during acclimatization, at commencement of the experiments and twice within a week throughout the duration of the experiment, using an electronic analytical and precision balance (BA210S, $d=0.0001 \mathrm{~g}$ ) (Satorius GA, Goettingen, Germany).

Experimental procedures involving the animals and their care were conducted in conformity with International, National and institutional guidelines for the care of laboratory animals in Biomedical Research and Use of Laboratory Animals in Biomedical Research as promulgated by the Canadian Council of Animal Care (CCAC, 1985). Further the animal experimental models used conformed to the guiding principles for research involving animals as recommended by the Declaration of Helsinki and the Guiding Principles in the Care and Use of Animals (American Physiological Society, 2002). 
Acute oral toxicity study of Moringa oleifera leaves extract: The acute oral toxicity study for Moringa oleifera leaves extract was conducted using the Organization for Economic Cooperation and Development (OECD) (2000).

Guidance Document on Humane End points that should reduce the overall suffering of animals used in this type of toxicity test. The test used was the limit dose test of the up and down procedure. Briefly, 5 animals were weighed and individually identified. The first animal was given the test dose - Moringa oleifera leaf extract $2000 \mathrm{mg}$ per $\mathrm{kg}$ body weight. The second and third animals were concurrently dosed and the fourth and fifth animals sequentially dosed.

This test demonstrated no deaths of Wistar rats dosed $2000 \mathrm{mg} \mathrm{kg}^{-1}$ body weight of the plants extract both within the short and long outcome of the limit dose test of Up and Down method. The LD50 was calculated to be greater than $2000 \mathrm{mg} \mathrm{kg}^{-1}$ body weight, orally.

Animal Grouping and Experimental Design: Forty male adult (10 to 12 weeks old) Wistar rats weighing 180-210 g were used for this research work. The rats were randomly divided into four groups of ten rats each such that the average weight difference between and within groups did not exceed $\pm 20 \%$ of the average weight of the sample population.

The first group animals were each given peanut oil (the vehicle) $300 \mathrm{mg} \mathrm{kg}^{-1}$ body weight (b.wt.), daily per oral (p.o), for 56 days, after saline $5 \mathrm{ml} \mathrm{kg}^{-1} \mathrm{~b}$. wt., daily p.o for 56 days to serve as the control.

The Moringa oleifera-alone group received physiological saline $5 \mathrm{ml} \mathrm{kg}^{-1}$ b. wt., daily p.o for 56 days followed by Moringa oleifera $300 \mathrm{mg} \mathrm{kg}^{-1}$ b.wt., daily p.o for another 56 days.

The alcohol-alone group was given alcohol (25\% ethanol) $5 \mathrm{mg} \mathrm{kg}^{-1}$ b. wt., daily p.o for 56 days followed by saline $5 \mathrm{ml} \mathrm{kg}^{-1}$ b.wt., daily p.o for another 56 days (Hussein et al., 2007).

The alcohol plus Moringa oleifera group were similarly given alcohol, but had Moringa oleifera 300 $\mathrm{mg} \mathrm{kg}^{-1}$ b.wt., daily p.o post-treatment for another 56 days.

The extract and alcohol were administered once daily by 12 noon for six days (Monday to Saturday) within a week. All the animals were sacrificed 24 hours after the last dosing.

Animal sacrifice and sample collection: Each rat was at the time of sacrifice was first weighed and then anaesthetized by placing it in a closed jar containing cotton wool sucked with chloroform anesthesia. The abdominal cavity was opened up through a midline abdominal incision to expose the liver. Then the liver was excised and trimmed of all fat. The liver weight of each animal was evaluated with an electronic analytical and precision balance (BA 210S, $d=0.0001$ - Sartoriusen GA, Goettingen, Germany). The liver volume was measured by water displacement method.

A portion of the median lobe of the liver was dissected and fixed in fixed in $10 \%$ formol-saline for histological examination. The remaining parts of the liver were frozen quickly in dry ice and stored at $25^{\circ} \mathrm{C}$ for biochemical analysis.

Histological Procedures and Analysis: This was done as described by Saalu et al., (2008). Briefly, the organs were cut on slabs about $0.5 \mathrm{~cm}$ thick and fixed in $10 \%$ formol saline for a day after which they were transferred to $70 \%$ alcohol for dehydration. The tissues were passed through 90\% alcohol and chloroform for different durations before they were transferred into two changes of molten paraffin wax for $20 \mathrm{~min}$ each in an oven at $57^{\circ} \mathrm{C}$. Serial sections of $5 \mu \mathrm{m}$ thick were obtained from a solid block of tissue and were stained with haematoxylin and eosin stains, after which they were passed through a mixture of equal concentration of xylene and alcohol. Following clearance in xylene, the tissues were oven- dried. Photomicrographs were taken with a JVC colour video digital camera (JVC, China) mounted on an Olympus light microscope (Olympus UK Ltd, Essex,UK).

Estimation of liver marker enzymes: The alanine transaminase, aspartate transaminase, alkaline phosphatase and Gamma-Glutamyl transpeptidase activities were evaluated using a commercially available kit. Detailed procedures for the above measurements were performed according to the kit manufacturer's instructions.

Determination of the biomarkers of liver Oxidative Stress: Assay of superoxide dismutase (SOD) activity in liver was determined according to the method described by Marklund and Marklund, 1974.

Assay of glutathione peroxidase (GPx) activity was determined with the help of a GPx assay kit. Detailed procedures for the above measurements were performed according to the kits' protocol.

Assay of catalase (CAT) activity was obtained by the method described by Ferro et al., 2010. Assay of liver 
reduced glutathione (GSH) concentration was done by the method of Moron et al., 1979.

Determination of liver Malondialdehyde (MDA) contents: Lipid peroxidation was evaluated on the basis of MDA level, and MDA in liver was determined using the method described by Jain et al., 1987.

Statistical analysis: All data were expressed as mean \pm SD of number of experiments $(n=10)$. The level of homogeneity among the groups was tested using Analysis of Variance (ANOVA) as done by Snedecor and Cochran 1980. Where heterogeneity occurred, the groups were separated using Duncan Multiple Range Test (DMRT). A value of $p<0.05$ was considered to indicate a significant difference between groups (Duncan, 1957).

\section{RESULTS}

Body Weight Changes: Table 1 shows that rats in control and Moringa oleifera (MO)-alone groups significantly $(p<0.05)$ increased in weight from their initial mean live weight. Both Alcohol- administered groups lost weights when compared with their initial weights. However, the weight loss by the Alcoholadministered alone rats was higher $(p<0.001)$ than the losses by the group that received $\mathrm{MO}$ after alcohol abuse $(p<0.05)$.

Weights and Volumes of livers: The liver weights, liver weight/body weight ratio and volumes of the Alcohol-alone rats were the least, being significantly lower $(p<0.001)$ compared to the mean liver weights, liver weight/body weight ratio and volumes of the Alcohol administered rats that in addition had $\mathrm{MO}$, which in turn were also lower but not significantly $(p>0.05)$ lower than those of the control and $\mathrm{MO}$-alone rats (Table 1 ).

\section{Liver oxidative stress}

Activities of liver enzymes- superoxide dismutase (SOD), catalase (CAT) and glutathione peroxidase (GPx): As shown in table 2, treatment with of Moringa oleifera (MO) alone and the control rats did not demonstrate any change in liver SOD, CAT and GPx activities. Alcohol-alone administration in rat however, showed a statistically significant reduction in SOD, CAT and GPx activities compared to control animals. Administration of $\mathrm{MO}$ after alcohol challenge significantly increased the liver SOD, CAT and GPx activities compared to animals that received alcohol alone.

Liver content of glutathione (GSH) and malondialdehyde (MDA): There was no significant $(p>0.05)$ change in the liver content of GSH and MDA following treatment with $\mathrm{MO}$ when compared with the control group. However, a significant $(p<$ 0.001 ) reduction in GSH content as well as a significant increase in MDA content were observed after alcohol-alone treatment when compared to the control animals. Administration of $\mathrm{MO}$ following alcohol abuse, however, significantly elevated the liver content of GSH, but also significantly reduced the liver content of MDA compared to animals that were given alcohol alone (Figure 2).

The activities of serum hepatic biomarker enzymes: As shown in figure 3, alcohol administration to Wistar rats increased serum alanine transaminase (ALT), aspartate transaminase (AST), alkaline phosphatase (ALP) and Gamma-Glutamyl transpeptidase (GGT), indicating severe hepatotoxicity. Post-treatment with $\mathrm{MO}$ after alcohol challenge however, showed a significant reduction of these liver biomarker enzymes to near control and $\mathrm{MO}$ alone values.

Liver Histology: An assessment of the histological profiles of the livers showed that the control group of Wistar rats showed normal liver profiles comprising of hepatocytes arranged in cords radiating from a central vein (Figure 1).

After prolonged exposure to alcohol, there was a marked distortion of the liver cyto-architecture resulting from degeneration of the liver parenchyma (Figure 2).

As shown in Figure 3, the livers of the group that had Moringa oleifera (MO) treatment after alcohol challenge exhibited a remarkable preservation in their histological profiles comparable to the control animals.

\section{DISCUSSION}

Chronic alcohol consumption induces hepatic oxidative stress due to increased generation of reactive oxygen species and/or reduced antioxidant capacity (Seitz et al., 2005).

The liver receives the most susceptible to damage in chronic alcohol ingestion because the portal vein drains the intestines directly to the liver and due to the fact that approximately $80 \%$ of ingested alcohol is metabolized in the liver (Tuma and Casey, 2003).

The results from this research showed that prolonged alcohol administration decreased the absolute testicular weights, testicular weight/body weight ratio and testicular volumes of rabbits. The Wistar rats that 
were treated with Moringa oleifera after alcohol administration however, showed a largely preserved testis weights, testis weight/body weight ratio and testis volumes. Our results in this regards is in consonance with the findings Ismail et al. (2007), who used a rabbit experimental model.

The liver histological profiles of all the groups of rats that received alcohol indicated various alterations of the liver morphology. Several research reports have also shown similar patterns (Sillanaukee, 1996; Nanji et al., 2001; Lieber, 2004). However, as was the case with the gross anatomical parameters and for probably similar reasons, post-treatment with Moringa oleifera showed a notable attenuation in the liver histological profiles.

In the present study, hepatotoxicity and oxidative stress mediated by alcohol abuse are exhibited by a significant increase in the activities of antioxidant enzymes, SOD, CAT, GPx and the liver content of MDA, and a significant decrease of GSH. Strikingly, post-administration of Wistar rats with leaf extract of Moringa oleifera remarkably modulated the oxidative stress caused by alcohol administration. This is potentials of Moringa oleifera had been demonstrated in our earlier study (Saalu et al., 2011).

Our results showed that administration of ethanol significantly $(P<0.001) \quad$ increased the serum intracellular enzymes namely alanine aminotransferase (AST), alkaline phosphatase (ALP), aspartate aminotransferase (ALT) and GammaGlutamyl transpeptidase (GGT), indicating severe hepato-toxicity (Saravanan et al., 2006). However, administration of MO decreases significantly these enzyme levels. The reversal of elevated serum intracellular enzyme levels by $\mathrm{MO}$ extract after ethanol administration may be attributed to the stabilizing ability of the cell membrane preventing enzymes leakages as earlier postulated by Pari and Karthikesan (2007).

Numerous scientific reports have shown elevation of a variety of antioxidant enzymes and organ biomarkers as a result of treatment with $M$. oleifera or with phytochemicals isolated from $M$. oleifera (Faizi et al., 1994; Kumar and Pari 2003; Saalu et al., 2011). This could provide an explanation for the finding in our study that MO administration after alcohol challenge in Wistar rat showed improved liver histology, function and oxidative stress.

\section{CONCLUSION}

Clearly, our study proves the beneficial effect of the Moringa oleifera leaf extract in protecting animals against alcohol-induced liver oxidative damage. It could also be extrapolated that this attenuating potential of Moringa oleifera leaf extract could be at least in part due to its free radicals scavenging capability.

Table 1: The changes in gross anatomical parameters of Wistar rats.

\begin{tabular}{|l|l|l|l|l|l|l|}
\hline $\begin{array}{l}\text { Treatment } \\
\text { groups }\end{array}$ & $\begin{array}{l}\text { Initial Body } \\
\text { Weight } \mathbf{( g )}\end{array}$ & $\begin{array}{l}\text { Final Body } \\
\text { Weight (g) }\end{array}$ & $\begin{array}{l}\text { Body Weight } \\
\text { Diff.(g) }\end{array}$ & $\begin{array}{l}\text { Testis Weight } \\
(\mathbf{g})\end{array}$ & $\begin{array}{l}\text { Testis } \\
\text { Volume } \\
(\mathbf{m L})\end{array}$ & $\begin{array}{l}\text { Testis } \\
\text { Body Wt ratio }\end{array}$ \\
\hline Control & $190.7 \pm 4.5$ & $200.6 \pm 4.3$ & $10.1^{\mathrm{a}}$ & $1.5 \pm 0.8$ & $1.5 \pm 0.4$ & 0.007 \\
\hline MO-alone & $189.2 \pm 7.8$ & $199.4 \pm 4.5$ & $10.2^{\mathrm{a}}$ & $1.5 \pm 0.4$ & $1.8 \pm 0.3$ & 0.006 \\
\hline Alcohol-alone & $198.4 \pm 5.7$ & $145.6 \pm 3.6$ & $51.8^{\mathrm{b}}$ & $0.5 \pm 0.6^{\mathrm{b}}$ & $0.5 \pm 0.4^{\mathrm{b}}$ & $0.003^{\mathrm{b}}$ \\
\hline Alcohol + MO & $200.5 \pm 4.4$ & $187.5 \pm 4.3$ & $13.1^{\mathrm{a}}$ & $1.4 \pm 0.6$ & $1.3 \pm 0.3$ & 0.005 \\
\hline
\end{tabular}

${ }^{\mathrm{a}, \mathrm{b}}$ represent significant decreases at $p<0.05$ and $p<0.001$ respectively when compared to control values.

Values are means \pm S.E.M. $n=10$ in each group. 
Am. J. Biotechnol. Mol. Sci., 2012, 2(1): 6-14

Table 2: Testicular Antioxidative Enzymes and testicular contents of GSH and MDA

\begin{tabular}{|l|l|l|l|l|l|}
\hline $\begin{array}{l}\text { Treatment } \\
\text { Groups }\end{array}$ & $\begin{array}{l}\text { SOD } \\
\text { (u/mg protein) }\end{array}$ & $\begin{array}{l}\text { CAT } \\
\text { (u/mg protein) }\end{array}$ & $\begin{array}{l}\text { GPx } \\
(\mathbf{n m o l} / \mathbf{m g} \text { protein) }\end{array}$ & $\begin{array}{l}\text { GSH } \\
\text { (nmol/mg protein) }\end{array}$ & $\begin{array}{l}\text { MDA } \\
(\mathbf{n m o l} / \mathbf{m g} \text { protein) }\end{array}$ \\
\hline Control & $48.6 \pm 4.1$ & $13.7 \pm 1.6$ & $0.8 \pm 0.1$ & $2.1 \pm 0.1$ & $0.7 \pm 0.3$ \\
\hline MO-alone & $45.7 \pm 4.5$ & $14.2 \pm 3.5$ & $0.7 \pm 0.2$ & $1.8 \pm 0.0$ & $0.9 \pm 0.2$ \\
\hline Alcohol-alone & $11.54 \pm 2.3 \mathrm{~b}$ & $4.3 \pm 2.5^{\mathrm{b}}$ & $0.2 \pm 0.1^{\mathrm{b}}$ & $0.9 \pm 0.2^{\mathrm{b}}$ & $3.3 \pm 0.5^{\mathrm{b}}$ \\
\hline Alcohol + MO & $31.4 \pm 2.5^{\mathrm{a}}$ & $12.7 \pm 0.3$ & $0.5 \pm 0.1^{\mathrm{a}}$ & $1.2 \pm 0.1$ & $1.9 \pm 0.03^{\mathrm{a}}$ \\
\hline
\end{tabular}

$\mathrm{a}, \mathrm{b}$ represent significant differences at $\mathrm{p}<0.5$ and $\mathrm{p}<0.001$ respectively compared to controls.

Values are means \pm S.E.M. $n=10$ in each group.

Table 3: Liver Marker Enzymes

\begin{tabular}{|c|c|c|c|c|c|}
\hline \multirow{2}{*}{$\begin{array}{l}\text { Treatment } \\
\text { Groups }\end{array}$} & \multirow{2}{*}{$\begin{array}{l}\text { Alanine } \\
\text { transaminas } \\
\mathrm{e} \\
\mathrm{u} / \mathrm{L}\end{array}$} & \multirow{2}{*}{$\begin{array}{l}\text { Aspartate } \\
\text { transaminase } \\
\quad \mathrm{u} / \mathrm{L}\end{array}$} & \multirow{2}{*}{$\begin{array}{l}\text { Alkaline phosphatase } \\
\text { u/L }\end{array}$} & \multicolumn{2}{|c|}{ Gamma-Glutamyl transpeptidase } \\
\hline & & & & $\mathrm{u} / \mathrm{L}$ & \\
\hline $\begin{array}{l}\text { Control } \\
\text { MO-alone } \\
\text { Alcohol-alone } \\
\text { Alcohol + MO }\end{array}$ & $\begin{array}{l}100.3 \pm 2.4 \\
101.5 \pm 3.6 \\
220.4 \pm 2.3^{b} \\
120.5 \pm 2.6\end{array}$ & $\begin{array}{l}50.0 \pm 1.0 \\
45.3 \pm 1.7 \\
100.3 \pm 1.9^{b} \\
45.5 \pm 2.7\end{array}$ & $\begin{array}{l}55.3 \pm 2.5 \\
58.4 \pm 2.7 \\
100.4 \pm 1.7^{b} \\
50.4 \pm 3.6\end{array}$ & $\begin{array}{l}12.4 \pm 4.7 \\
10.5 \pm 1.2 \\
18.3 \pm 1.4^{a} \\
16.2 \pm 2.5\end{array}$ & \\
\hline
\end{tabular}

a, b represent significant differences at $\mathrm{P}<0.05$ and $\mathrm{P}<0.001$ respectively when compared to the control values..

Values are means \pm S.E.M. $n=10$ in each group.

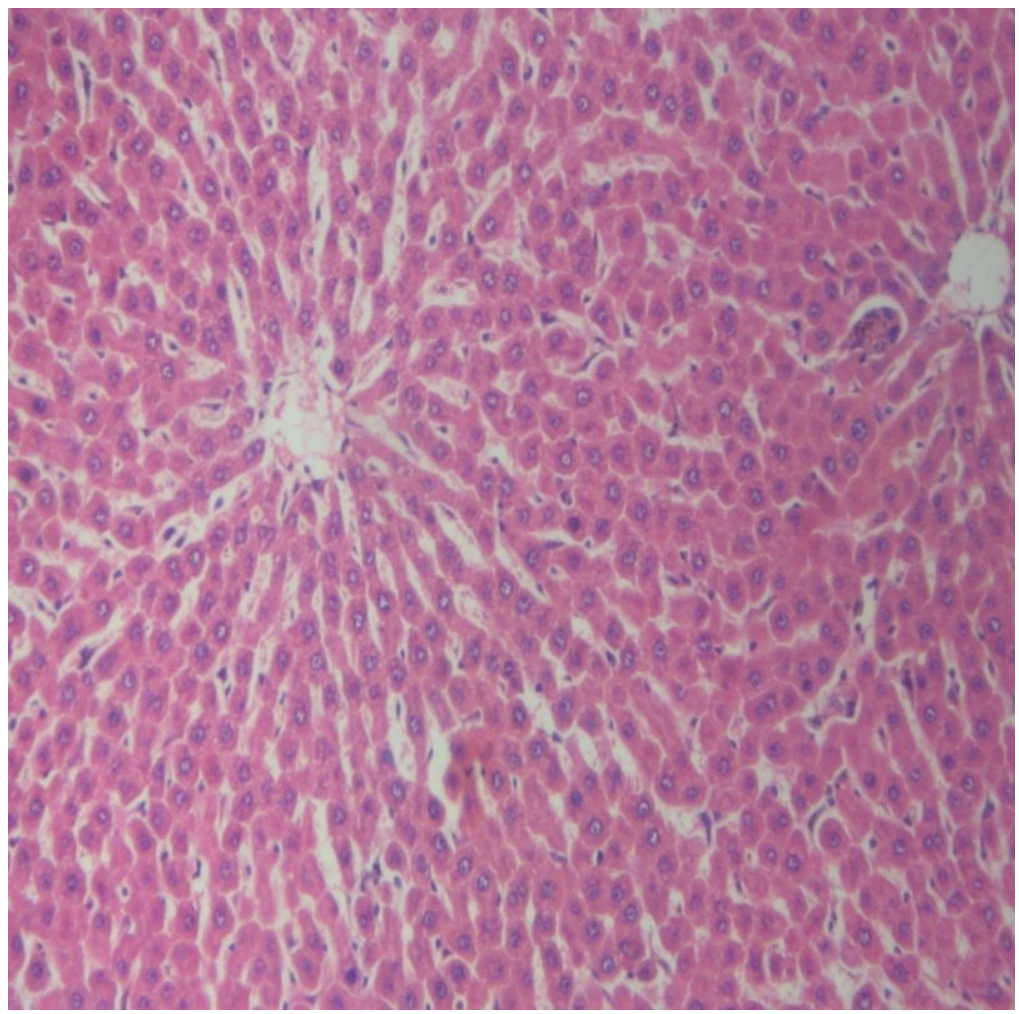

Fig 1: A representative section of an untreated control Wistar rat liver. Showing the normal structure of liver tissue composing of hepatocytes arranged in cords radiating from a central vein

(X 400 magnification, hematoxylin and eosin stain) 
Am. J. Biotechnol. Mol. Sci., 2012, 2(1): 6-14

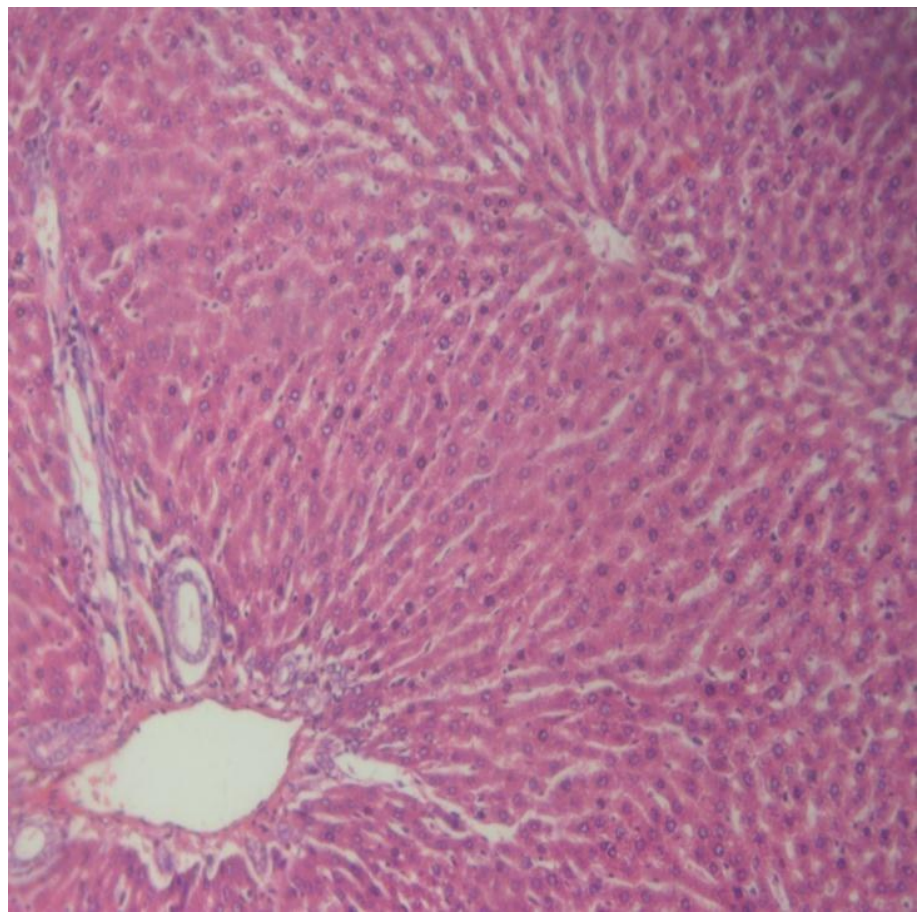

Fig 2. A sectional view of the liver of rat which received alcohol ( $25 \%$ ethanol) without Moringa oleifera posttreatment. Showing hepatic damage and degeneration. There are also irregular collagenous fibers and dilatation of the portal vein. (X100 magnification, hematoxylin and eosin stain).

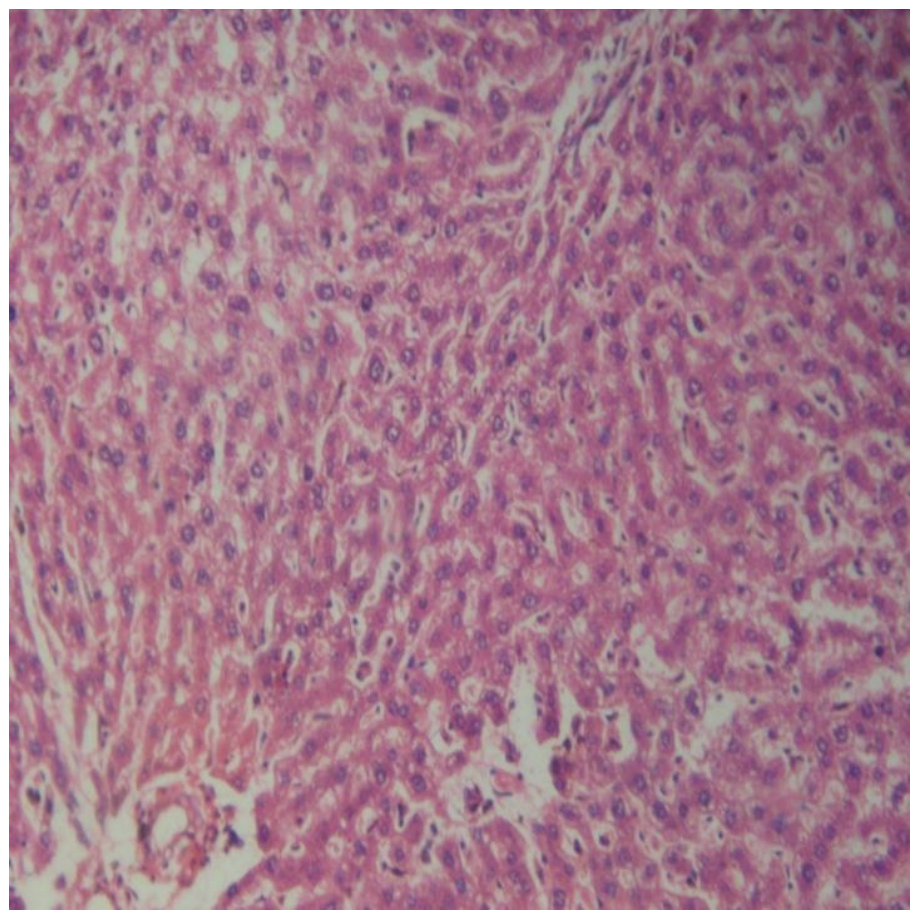

Fig 3: A representative section of rat liver administered alcohol (25\% ethanol), followed by Moringa oleifera posttreatment. Showing marked improvement in liver pararencymal degenerative changes. (X 100 magnification, hematoxylin and eosin stain) 


\section{REFERENCES}

American Physiological Society, 2002. Guiding principles for research involving animals and human beings. Am J Physiol Regul Integr Comp Physiol., 283: 281-283.

Aslam, M. F., Anwar, R., Nadeem, U., Rashid, T.G., Kazi, A., Nadeem, M (2005). Mineral composition of Moringa oleifera leaves and pods from different regions of Punjab, Pakistan. Asian J. Plant Sci., 4: 417-421.

Canadian Council of Animal Care, 1985. Guide to the handling and Use of experimental animals. Ottawa: Ont.; 2 United States NIH publications, no. $85-23$ : 45-47.

Caceres, A., Cabrera, O., Morales, O., Mollinedo, P., Mendia, P (1991) Pharmacological properties of Moringa oleifera. 1: Preliminary screening for antimicrobial activity. J. Ethnopharmacol., 33: 213-216.

Chambers, R.E.; Stross, P.; Barry, R.E.; Whicher, J.T (1987). Serum amyloid A protein compared with Creactive protein, alpha 1-antichymotrypsin and alpha 1acid glycoprotein as a monitor of inflammatory bowel disease. Eur. J. Clin. Invest. 17, 460-467.

Diehl, A.M (2002). Liver disease in alcohol abusers: clinical perspective Alcohol, 27(1): 7-11.

Duncan, B.D (1957). Multiple range tests for correlated and heteroscedastic means. Biometrics, 13: 359-364.

Ferro, C., Chagas, V.L., de Oliveira, M.F., de Oliveira, P.L., Schanaider, A (2010). Catalase activity in lung, kidney and small bowel non-ischemic in rats after intestinal reperfusion. Rev. Col. Bras. Cir. 37, 31-38.

Fuglie, L.J (1999). The Miracle Tree: Moringa oleifera: Natural Nutrition for the Tropics. Church World Service, Dakar. 68 pp.; revised in 2001 and published as The Miracle Tree: The Multiple Attributes of Moringa, 172

Ghasi, S., Nwobobo, E., Ofili, J.O (2000). Hypocholesterolemic effects of crude extract of leaf of Moringa oleifera Lam in high-fat diet fed Wistar rats. J. Ethnopharmacol., 69: 21-25.

Hussein, J.S., Oraby, F.S. and El-Shafy, N (2007). Antihepatotoxic effect of garlic and onion oils on ethanol-induced liver injury in rats. J. Appl. Sci. Res., 3(11): 1527-1537.

Ismail, A.M., Sedki, A.A. and Abdallah, A.G (2003). Influence of black seed, garlic and onion supplementation on reproductive performance in rabbits. Egypt J. Agric. Res., 81: 1193-1207.

Jain, S.K., McVie, R., Duett, J., Herbst, J.J (1989).Erythrocyte membrane lipid peroxidation and

glycosylated hemoglobin in diabetes. Diabetes, 38, 15391543
Kumar, N.A. and Pari, L (20030. Antioxidant action of Moringa oleifera Lam. (drumstick) against antitubercular drugs induced lipid peroxidation in rats. J. Med. Food, 6(3): 255-259.

Kurma, S.R. and Mishra, S.H (1998). Antiinflammatory and hepatoprotective activities of fruits of Moringa Ind. J. Nat. Prod., 14: 3-10.

Larson, R.A (1988). The antioxidants of higher plants. Phytochemistry, 27: 969-978.

Lieber, C.S (2004). Alcoholic fatty liver: Its pathogenesis and mechanism of progression to inflammation and fibrosis. Alcohol, 34, 9-19.

Marklund, S. and Marklund, G (1974). Involvement of the superoxide anion radical in the autoxidation of pyrogallol and a convenient assay for superoxide dismutase. Eur. J. Biochem. 47, 469-474.

Moron, M.S., Depierre, J.W., Mannervik, B (1979). Levels of glutathione, glutathione reductase and glutathione S-transferase activities in rat lung and liver. Biochim. Biophys. Acta, 582, 67-78.

Nanji, A.A., Jokelainen, K., Fotouhinia, M., Rahemtulla, M., Thomas, P. and Tipoe, G.L (2001). Increased severity of alcoholic liver injury in female rats: role of oxidative stress,

National Research Council, (2006). "Moringa", Lost Crops of Africa, Vol. 2. Vegetables Lost Crop of Africa, National Academics Press

Pari, L. and Karthikesan, K (2007). Protective role of caffeic acid against alcohol - induced

biochemical changes in rats. Fundamental \& clinical pharmacology, 21(4): 355-361.

OECD. (2000). Guidance document on acute oral toxicity. Environmental Health and Safety monograph series on Testing and Assessment, 24. 35-38.

Oliveira, J.T.A., Silveira, S.B., Vasconcelos, K.M., Cavada, B.S., Moreira, R.A (1999). Compositional and nutritional attributes of seeds from the multiple purpose tree Moringa oleifera Lamarck. J Sci Food Agric. 1999; 79(6):815-20.

Ram J. 1994. Moringa: A Highly Nutritious Vegetable Tree. Tropical Rural and Island/Atoll

Saalu, L.C., Jewo, P.I., Fadeyebi, I.O. and Ikuerowo, S.O (2008). The effect of unilateral varicocele on contralateral testicular Histo-morphology in Ratus Norvegicus. J. Med. Sci., 8(7): 654-655.

Saalu, L.C., Osinubi, A.A., Akinbami, A.A., Yama, O.E., Oyewopo, A.O., Enaibe, B.U (2011). Moringa oleifera Lamarck (drumstick) Leaf Extract Modulates the Evidences of Hydroxyurea -Induced Testicular Derangement International Journal of Applied Research in Natural Products Vol. 4 (2), pp. 32-45. 
Saravanan, R., Viswanathan, P. and Pugalendi, K.V (2006). Protective effect of ursolic acid

on ethanol-mediated experimental liver damage in rats. Life sciences, 78: 713-718.

Seitz, H.K., Lieber, C.S., Stickel, F., Salaspuro, M., Schlemmer, H.P. and Horie, Y (2005). Alcoholic liver disease: From pathophysiology to therapy. Alcohol. Clin. Exp. Res., 29:1276-1281.

Siddhuraju, P. and Becke, K (2003). Antioxidant properties of various solvent extracts of total phenolic constituents from three different agroclimatic origins of drumstick tree (Moringa oleifera Lam) leaves. J Agric Food Chem. 2003; 51(8):2144-55.

Sillanaukee, P (1996). Laboratory markers of alcohol abuse. Alcohol. 31:613-6.

Snedecor, G.W. and Cochran, W.G (1980). Statistical Method, 7th edn. lowa: lowa State University Press, 215.
Tahiliani P. and Kar, A (2000). Role of Moringa oleifera leaf extract in the regulation of thyroid hormone status in adult male and female rats. Pharmacol. Res., 41: 319-323.

Tuma, D.J. and Casey, C.A (2003). Dangerous byproducts of alcohol breakdown-focus on adducts. Alcohol Res Health, 27:285-90.

Venkatraman, A., Shiva, S., Wigley, A., Ulasova, E., Shhieng, D. and Bailey, S.M (2004). The role of iNOS in alcohol-dependent hepatotoxicity and mitochondrial dysfunction in mice. Hepatology, 40:565-73.

Wei, H., Derson, Y., Xiao, S., Li, L., Zhang, Y (1999). Alcohol consumption and alcohol-related

problems: Chinese experience from six area samples, 1994. Addiction. 94(10), 1467-1476. 